\title{
The Legacy of Dada a Century Later
}

\author{
Dr. Doina Uricariu \\ 111 South Elliott Place, Brooklyn, NY 11217, USA \\ doina.uricariu@gmail.com
}

\begin{abstract}
:
A personal view of the art of our century, dealing with separate subjects that seem important for an understanding of Dadaism, modernism and post-modernism from the beginning of a sense of modernity in European Culture, that is roughly from 1880s to 1914-1916.

Charles Peguy considered that "the world has changed less since the time of Jesus Christ than it has in the last thirty years".

How long can this engine resist producing a changement of all conditions of Western, Eastern and American societies, from its sense of history, beliefs, pieties, modes of production, the idea of itself, its art, the refusal and rejection of social significance? Are the artists of our time still in the same state of great convulsion, social tumult, and cultural turmoil?

Have we the sense of an accelerated rate of change in all areas of human discourse and languages, including art? The Dadaists were alive at the beginning of modernism along with the Futurist, Cubist, Surrealist, and Expressionist artists. Today, we live at the end of modernism.

Dadaism created the modernist laboratory, an arena of significant experiments. Now

Dadaism is relegated to a period room in the museums, a series of exhibitions presented by Ian Dunlop in an important book entitled The Shock of the New, published in London and New York, the same year, in 1972.

In 2013, Robert Hughes published an oustanding volume with the same title, The Shock of the New, presenting the hundred-year History of Modern Art, its rise, dazzling achievement, and fall. What has our culture lost at the end of XXth century, in 1980, 1990 and 2016 that the avant-garde had in 1880, 1890, 1916 ? Idealism offered a belief that formed an immense territory to explore, new metaphors such as Tour Eiffel, the new sculpture such as Brancusi's oeuvre and its Birds in Space, the mechanical paradise of the ready-made, the cadavre esquis, the romance of technology, the evironment and the landscape, the city, and the metropolis. The view from the train/from the plane was neither the view of the eagle nor the view of the frog, mentioned by Friedrich Nietzsche. It was neither the view of the horse, nor of la fourmillante cite of Baudelaire, the machine-made environment, the city.
\end{abstract}

\section{The Legacy of DADA a Century Later}

I have forced myself to contradict myself in order to avoid conforming to my taste. I don't believe in art. I believe in artists. (Marcel Duchamp)

DADA after a Century and how might we understand the idea, the concept and the legacy of DADA? How can we do this today, in 2016? Thinking and working against banal and facile generalizations. DADA has been presented in terms of non-sense, anti-art, and absurdity. The Romanian and European Tristan Tzara asserted that the word DADA meant nothing-ne signifie rien.

DADA displayed skepticism with regards to accepted values
DADA's artefacts and performances project an image of group camaraderie and multi-signature manifestos vs. individualism

DADA, an abiding legacy for the century to come with programs, manifestoes and strategies that include ready-mades, performance, collage, assemblage, montage, media, chance, prankish mind and behavior, and different forms of automatization, photomechanical reproductions and printed ephemera

DADA's reconceptualization of artistic practice, as a form of tactics and strategies

DADA may have had the greatest influence on contemporary art of avant-garde movement

DADA's radicalism in concepts and strategies is foundational in modernism and postmodernism, 
representing today even a cliché, a déjà vu, a stereotype.

DADA's machine culture and anti-art

DADA in the movement's main centers: Zurich, Berlin, Cologne, Hannover, Paris, New York

DADA's "form of calculated irreverence" (Hugo Ball)

Dada's subversive reaction against the status quo of the system

DADA's "self-historicizing" (Tzara)

DADA's mischief-making

DADA in Eastern Europe

DADA's globalism and constellation of identities and ideas. Its aims were often supranational emerging amid the racially having a tinge of nationalistic discourse of W.W. I.

Leah Dickerman: "There had not been an artistic movement so self-consciously international".

DADA's promotion of a proto-globalized identity is evident in the stationary that Tristan Tzara produced for the movement Dada in Paris, by listing Dada branches below

DADA's global network of artists of diverse nationalities might be exemplified by Zurich and Cabaret Voltaire: Hans Arp (German-Swiss), Hugo Ball (German), Sophie Tauber, (Swiss-born), Marcel Ianco and Tristan Tzara (both Romanianborn), Walter Serner (Austrian of Germanexpression, born in Karlovy-Vary), Vikking Eggeling (Swedish), Emmy Hennings, (Germanborn and Hugo Ball's partner), the German Richard Huelsenbeck) and New York with John Covert (born in Pittsburg), Jean Crotti (born in Switzerland ,French-speaking), Marcel Duchamp, (French-born and naturalized American), the Brooklyn-born American Man Ray who spent most of his career in France, the French Francis Picabia, one of the early major figures of the Dada movement in United States, Italian-born Joseph Stella, who emigrated to New York, German-born Baroness Elsa von Freytag-Loringhoven, a central figure of Dada in the Greenwich Village, the Philadelphia-born American Morton Livingston Schamberg, one of the first American artists to explore the esthetic qualities of industrial subjects, Beatrice Wood, born in San Francisco and admirer of Marcel Duchamp, Great Potter called the "Mama of Dada" in a documentary film, written and directed by Thomas L. Neff.
DADA in Paris with Louis Aragon, Celine Arnauld, Hans Arp, Andre Bréton, Jean Crotti, Paul Dermée, Marcel Duchamp, Suzanne Duchamp, Paul Eluard, Max Ernst, Man Ray, Francis Picabia, Georges Ribemont-Dessaignes, Philippe Soupault, Tristan Tzara

DADA's antinationalism

DADA's compilation of materials, new technologies, and media promoted by iconoclastic credoes, manifestoes and commentaries.

DADA assumed like a generally SURREALISM. The first three exhibitions presented DADA in conjunction with surrealism:

-1936 Fantastic Art, Dada, Surrealism, exhibition presented at the Museum of Modern Art, New York

- 1968 Dada, Surrealism and their Heritage, Museum of Modern Art, New York

-1978 Dada and Surrealism Reviewed, Council of Great Britain

2005-2006

DADA, Centre Pompidou, Musée national d'art moderne, Paris, (Oct. 5, 2005- Jan. 9, 2006)

DADA, National Gallery of Art, Washington, DC, (Feb. 19, 2006-May 14, 2006)

DADA Museum of Modern Art, New York, (June 18-Sept.11, 2006)

-DADA and international art movements: Blaue Reiter, Cubism, Futurism, Expressionism, Constructivism.

There was a pressure exercised by the new experiences vs the demand for new forms to contain it, and to perform art as a work in progress.

A new perspective on the heroic and dynamic sense of cultural and artistic possibilitiy: Arthur Rimbaud's injunction être absolument moderne

NB William S. Rubin noted in exhibition catalogue Dada, Surrealism and their Heritage: "Dada was however the first programmatically international movement in the plastic arts".

DADA's supranational aspirations vs national cultural and artistic agendas

DADA's refusal / rejection of the transcendent and sublimated art as an illusionistic conjuring of imaginary worlds.

From the Apotheosis of machine to the apotheosis of computers and virtual artistic realities

DADA vs Minimalism. 


\section{Biographical Sketch: \\ Dr. Doina URICARIU}

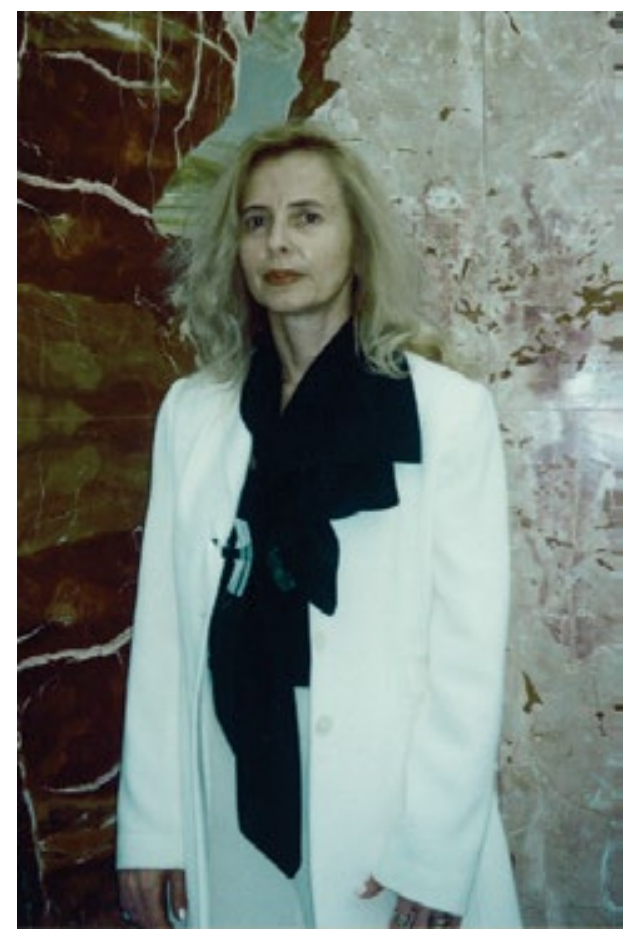

Doina Uricariu is an important contemporary Romanian writer with an unmistakable lyric voice born out of a generous sensuous universe, intersected by constant moral, philosophical, and political questioning. She started out in poetry with the volume Healings, published in 1976 after a seven-year wait in the hands of the Communist censorship. Eight other volumes of poetry followed: The Heart Institute, Jugastru Sfiala, Happy Beings, The Hand-covered Face, Atrocious Eye, The Heart Institute, The Power of Leviathan, The Axonometric Heart, one volume published by Khalit Lala National Academy in India, and three volumes of poetry published in Italy, En plein air, Architettura scavata/Excavated Architecture, Inserzioni sovversive/Subversive Insertions, Abitare in una lente, a bi-lingual GermanRomanian volume Das Herzinstitut/The Heart Institute. Doina Uricariu published in 2015 a volume of new poems, The Glass Book/Cartea de sticlă in different editions, one in Romanian, two editions in English $(2015,2016)$. The Glass Book was recently translated in French.

Mrs. Uricariu's poetry has been translated in anthologies and individual volumes in English, German, French, Italian, Swedish, Norwegian, Russian, Serbian, Czech, Hebrew, Albanian and in twenty other languages. She published volumes of criticism and literary history, essays, and art criticism that are considered milestones on their respective subjects: Apocrypha on Emil Botta, Ecorches, Nichita StănescuParadoxical Lyricism, Søren Kierkegaard, Maria Pillat-Brates: Poetry and Reverie, Antonovici: Sculptor on Two Continents, Vlaicu Ionescu: The Artist. Doina Uricariu prepared and edited reference editions on Emil Cioran, Dominic Stanca, Jeni Acterian, Emil Botta, and the Podrom Filokalia. She published four volumes of her memoirs in two books entitled The Lower Jaw and The Lions Stair.

Dr. Doina Uricariu is member of Romanian Writers Association, European Cultural Society, and the International PEN CLUB. She is a Knight of the Order of Faithful Service of Romania, distinction conferred by the President of the country, and Knight of the Order of the Romanian Crown bestowed by King Mihai I and Royal House of Romania. She was the Director of the Romanian Cultural Institute in New York (2013-2016). 